\title{
EVIDENCE FOR VALIDITY OF THE REVISED LEVINSON AND SANFORD ANTI-SEMITISM SCALE ${ }^{1,2}$
}

\author{
JOHN ASKEW AND D. GABRIELLE JONES-WILEY \\ Jackson State University
}

DIANE R. MOROVATI AND HOWARD B. LEE

California State University, Northridge

\begin{abstract}
Summary.-Jones-Wiley, Restori, Lee, and Ho (2007) updated and re-estimated the reliability and construct validity of the 1944 Levinson and Sanford Anti-Semitism Scale. Criterion validity was not adequately supported, given the small number of Jewish and Muslim participants. Two separate studies were conducted, (1) a comparison of Jewish, Muslim, and Christian religious groups on the Anti-Semitism score and (2) the correlation of political preference with the Anti-Semitism scores of college students and local community members. These two studies provide evidence supportive of the criterion validity of the revised scale.
\end{abstract}

Levinson and Sanford (1944) created a psychometrically sound 52-item scale with internal consistency reliabilities above .96 and evidence of construct validity. Jones-Wiley, Restori, Lee, and Ho (2007) confirmed that the scale still has high reliability $\left(r_{\mathrm{tt}}>90\right)$ based on data collected from college students in California. They were also able to shorten the scale to 32 -items using item-to-total correlations to evaluate contributions of the individual items. Jones-Wiley, et al. (2007) found that shorter scales of different length also had reliabilities exceeding .90 ; however, this 32 -item scale had the highest value. A 5-point response scale was used in place of the original 2 response scale. Justification for such a change was previously documented by Comrey (1978). The 5-point scale was constructed so a lower score indicated higher anti-Semitic attitudes (1: Strongly agree and 5: Strongly disagree). A factor analysis gave evidence of construct validity; however, criterion validity could not be adequately assessed given the small number of Muslim and Jewish participants. Helpful reviewers of that manuscript suggested the study of more participants from those two groups to assess more completely the discriminant validity. Acting on that suggestion, two studies were designed and are reported here. The purpose of Study 1 was to obtain information on discriminant validity. Study 2's goal was to examine evidence of criterion validity.

\footnotetext{
${ }^{1}$ All reprint requests should be addressed to Dr. D. G. Jones-Wiley, Department of Psychology, Jackson State University, P.O. Box 17550, Jackson, MS 39217.

${ }^{2}$ For a complete account of work done on the revised Levinson and Sanford Anti-Semitism Scale, write to Howard B. Lee, Department of Psychology, California State University, Northridge, CA 91330-8255.
} 


\section{STUdY 1}

For additional credit, students in a research course were asked to recruit volunteers in the local community. They were asked to approach the proper authorities to receive permission to obtain information from members of Christian churches, Jewish temples, and Muslim mosques. The religious preferences of 160 participants were identified. Three major classifications were created, Jewish, Muslim, and Christian. Other religious preferences were not considered. These categories of religious preference were compared on mean total score of the revised Levinson and Sanford Anti-Semitism Scale. Forty-seven who identified themselves as Muslim, 52 as Jewish, and 61 as Christian were recruited from various student, religious, and community organizations in the southern California area were asked by a student researcher to complete the 32-item version of the Levinson and Sanford scale. It was expected that the Muslim group would endorse anti-Semitic statements more than the Jewish group. Given the items of the response scale used, the Muslim group would have a lower mean score on the scale than the Jewish group's mean score. The Christian group would be expected to have a mean score which would fall between the means for Jewish and Muslim groups. Using a one-way analysis of variance, with Scheffé post boc tests, the obtained mean group differences $\left(M_{\text {Muslim }}=114.2, S D=12.0 ; M_{\text {Jewish }}=\right.$ 151.2, $\left.S D=5.9 ; M_{\text {Christian }}=145.9, S D=13.7\right)$ were in the expected direction and significant $\left(F_{2,161}=161.6, p<.01, \eta^{2}=.61\right)$. All three Scheffé post hoc comparisons were statistically significant $(p<.05)$. The Muslim group had the highest mean endorsement of anti-Semitic statements, while the Jewish group had the lowest endorsement. Even though the Christian group gave a significantly higher mean endorsement of anti-Semitic statements than the Jewish group, they showed a statistically lower endorsement than the Muslim group. The Muslim group also exhibited a larger variability of responses than the Jewish group; this wider variability may reflect sampling from the southern California area. Muslim participants were not asked about the strength of their belief or whether they were U.S.-born or foreign born, or what generation of Americans they represented. However, Jewish people might be more consistent and less variable in their responses to these anti-Semitic statements than the other two religious groups regardless of their generation or place of birth.

\section{STUDY 2}

In Study 2, the 173 participants consisted of 152 participants from the university's participant pool, 18 student volunteers from a nearby $2-y r$. college, and 3 adult friends and family members of one student research assistant. These 76 men and 97 women were asked by research assistants to complete the 32-item Levinson and Sanford Anti-Semitism Scale and to state 
their political preferences as 1: Radical right, 2: Ultra-conservative, 3: Conservative, 4: Middle-of-the-road, 5: Liberal, 6: Ultra-liberal, or 7: Radical left. This political preference scale was used and documented by Comrey, Wong, and Backer (1978) in a study of social conformity. The frequencies for each category were $5,10,35,62,50,9$, and 2 , respectively. The means and standard deviations on the rating scale and total revised Anti-Semitism Scale scores were, respectively, $M_{\text {Scale }}=4.0, S D=1.2 ; M_{\mathrm{AS}}=131.7, S D=28.4$. Based on the original estimate for validity from Levinson and Sanford (1944), it was hypothesized that scores on the Levinson and Sanford Anti-Semitism Scale would be positively correlated with scores on political preference. This means that those who are more conservative would tend to endorse antiSemitic statements higher. This expectation is consistent with previous findings (Echebarria-Echabe \& Guede, 2007) linking political conservatism with measures of authoritarianism and anti-Semitism. The present correlation was in the expected direction and statistically significant $(r=.48, p<.01)$. Women $(r=.51, p<.01)$ showed a somewhat stronger association of political preference with anti-Semitism than men $(r=.43, p<.01)$ as measured in the present study.

The internal consistency reliability was computed for the samples in each study. In Study 1, $\alpha$ was .96, and in Study 2, $\alpha$ was .98. These values were consistent with those reported by Jones-Wiley, et al. (2007). These two investigations using the 32-item Levinson and Sanford Anti-Semitism Scale give evidence supporting the validity of the scale. In Study 1, evidence of discriminant validity based on differences in scores among religious groups. Study 2 provided evidence of criterion validity through correlation of rated political preferences and scale scores. These findings are consistent with those of Jones-Wiley, et al. (2007) for criterion validity. However, additional research using a wider range of participants than those residing in southern California is required before one can state that this revised scale has utility in measuring anti-Semitism in a broad range of situations. It does, however, provide psychometric evidence supporting the scale developed over 64 years ago by Levinson and Sanford (1944).

\section{REFERENCES}

Comrey, A. L. (1978) Common methodological problems in factor analytic studies. Journal of Clinical and Consulting Psychology, 46, 648-659.

COMrey, A. L., Wong, C., \& Backer, T. E. (1978) Further validation of the Social Conformity scale of the Comrey Personality Scale. Psychological Reports, 43, 165-166.

Echebarria-Echabe, A., \& GuedE, E. F. (2007) A new measure of anti-Arab prejudice: reliability and validity evidence. Journal of Applied Social Psychology, 37, 1077-1091.

Jones-WILey, D. G., Restort, A. F., LeE, H. B., \& Ho, M. (2007) A research note on the Levinson and Sanford Anti-Semitism Scale. Perceptual and Motor Skills, 105, 1023-1026.

Levinson, D. J., \& SANFord, R. N. (1944) A scale for the measurement of anti-Semitism. Journal of Psychology, 17, 339-370. 